\title{
Utjecaj politicke stabilnosti na produktivnost rada u postsocijalističkom dijelu Europske unije
}

Filip Bašić

\author{
https://doi.org/10.31297/hkju.20.1.7 \\ UDK 321.7:338.24(4-191.2)(4-11) \\ 339.923:061.1](4)EU \\ Preliminary scientific report / prethodno znanstveno priopćenje \\ Received / primljeno: 24.5.2019. \\ Accepted/prihvaćeno: 14.2. 2020.
}

Politička stabilnost u velikoj mjeri djeluje na ekonomske performanse određene zemlje. U ovom će se radu primjenom panel-modela sa slučajnim efektom pokazati da politička stabilnost ima znatan utjecaj na produktivnost rada mjerenu BDP-om po zaposlenom. Pritom će se politička stabilnost određene zemlje procjenjivati s pomoću indikatora političke stabilnosti i izostanka nasilja/terorizma, rizika državnog udara i indikatora državne legitimnosti. U uzorak je odabrano 11 postsocijalističkih zemlja Europske unije od 2000. do 2017. godine. Provedena analiza pokazuje da politička stabilnost ima bitan utjecaj na produktivnost rada u postsocijalističkim europskim zemljama te je robusnost rezultata dodatno potvrđena provođenjem analize pri alternativnim specifikacijama. S obzirom na to da

Filip Bašić, doktorski student Ekonomskog fakulteta Sveučilišta u Zagrebu (PhD student at the Faculty of Economics, University of Zagreb, Croatia, e-mail: filipbasic6@gmail.com).

ORCID ID: https://orcid.org/0000-0001-9338-0011 
se u postojećim radovima većinom nastojalo otkriti uzroke političke nestabilnosti i kako ih spriječiti, ovaj rad stavlja naglasak na posljedice političke nestabilnosti na produktivnost i gospodarstvo u cjelini.

Ključne riječi: politička stabilnost, produktivnost, postsocijalističke zemlje, Europska unija

\section{Uvod}

Poduzeća su svakodnevno izložena brojnim eksternim faktorima na koje nemaju utjecaj, ali koji znatno utječu na njihovo poslovanje. Pritom se politička situacija često izdvaja kao izrazito bitan faktor za razvoj poduzeća i rast gospodarstva u cjelini (Barro, 1991; Alesina, Ozler, Roubini \& Swagel, 1996). Osoba ili stranka na vlasti odgovorne su za organizaciju i djelovanje zakonodavne i izvršne vlasti, provođenje fiskalne politike te rješavanje drugih nacionalnih pitanja kako bi se poboljšalo blagostanje u zemlji. Međutim, pojedine odluke mogu dovesti do nezadovoljstva građana te gubitka povjerenja, što dovodi do rasta političke nestabilnosti u zemlji. Ekonomisti političku nestabilnost smatraju ozbiljnom prijetnjom gospodarskom napretku jer nerijetko dovodi do donošenja kratkoročnih suboptimalnih makroekonomskih odluka (Aisen \& Vega, 2011).

Potrebno je istaknuti da je do sada objavljen vrlo malen broj znanstvenih radova koji obrađuju tu temu. Međutim, različiti autori u puno su većem obujmu istraživali kako na nacionalnu produktivnost utječu pojedine odluke i postupci vlade. Tako je Fernald (1999) istraživao postoji li korelacija između javnog kapitala i produktivnosti. S druge strane, Ahearn, Yee i Huffman (2002) usredotočili su se na utjecaj državne politike na produktivnost u sektoru poljoprivrede. Kneller i Misch (2013) proučavali su kako struktura javnih izdataka utječe na produktivnost poduzeća, dok su Borkovic i Tabak (2018) stavili naglasak na visinu javnih investicija. Salotty i Trecroci (2016) proučavali su povezanost produktivnosti i državnog duga, izdataka te poreza. Potrebno je spomenuti i rad Giordana i suradnika (2015) koji su nastojali utvrditi kako neefikasnost javnog sektora sputava produktivnost poduzeća u određenoj zemlji. Ovim će se radom nastojati dopuniti postojeća istraživanja o produktivnosti te istodobno upozoriti na važnost političke stabilnosti u suvremenim ekonomijama.

Cilj je ovog rada utvrditi kako politička stabilnost utječe na produktivnost rada u postsocijalističkom dijelu Europske unije. Počevši s istraživanjem 
Solowa (1957), usporedba i analiza produktivnosti faktora proizvodnje dobila je važnu ulogu u makroekonomiji (Bernard \& Jones, 1996). Kako bi se analizirao utjecaj na produktivnost rada, u prvom dijelu rada napravit će se pregled sličnih istraživanja te će se utvrditi na koje su sve načine različiti autori definirali i mjerili političku stabilnost. U drugom dijelu naglasak će biti stavljen na metodologiju te na varijable koje se upotrebljavaju u regresijskom modelu. Potom će se prezentirati rezultati istraživanja, a na kraju će biti iznesen zaključak rada uz prijedloge za daljnja istraživanja.

\section{Pregled dosadašnjih istraživanja}

Politička stabilnost širok je pojam koji se s jedne strane odnosi na stabilnost vlade i političkog režima, dok s druge strane pokriva stabilnost unutarnjega pravnog sustava te izvanjsku stabilnost (Akongdit, 2013). Pritom malen broj autora strogo definira političku stabilnost jer smatra da je kao pojam samoobjašnjiva te je stoga nije potrebno posebno opisivati (Castles, 1974). Štoviše, do sredine 1960-ih politička stabilnost općenito se definirala kao kontinuitet određenoga političkog sustava (Lipset, 1963).

Hunvitz (1973) definira političku stabilnost preko određenih osnovnih karakteristika poput izostanka nasilja, trajanja i kontinuiteta vlade, postojanja legitimnoga ustavnog uređenja, izostanka strukturnih promjena te kao višestruki socijalni atribut. $\mathrm{S}$ druge strane, izostanak nasilnih političkih događaja čini se kao ključni element definicije političke stabilnosti (Mohamed, 2015). Pritom je nasilne političke događaje moguće podijeliti u tri osnovne kategorije (Dimitraki, 2010): događaji koji su prijetnja određenoj državi na političkoj i ekonomskoj razini poput revolucija i kriza vlade; događaji kojima građani izražavaju nezadovoljstvo političkim režimom na vlasti općim štrajkovima, prosvjedima ili protuvladinim demonstracijama; izrazito nasilni događaji između suprotstavljenih strana koji se očituju u pokušajima atentata ili gerilskom ratovanju.

Još od ranih istraživanja (Venieris \& Gupta, 1986; Gupta, 1990) brojni istraživači nastojali su utvrditi na koje sve načine politička stabilnost utječe na ekonomske performanse. Overland i suradnici (2005) smatraju da politička stabilnost ima izravan utjecaj na ekonomsku politiku i poslovno okruženje te da političke promjene dovode do nesigurnosti u donošenju poslovnih odluka, što izravno utječe na smanjenje investicija i odljev kapitala. To je u skladu s istraživanjem Matta, Appletona i Bleaneyja (2017) u kojem pokazuju da nestabilnost vlade popraćena masovnim civilnim pro- 
svjedima može znatno djelovati na smanjenje proizvodnje koja se neće oporaviti sljedećih pet godina.

Do slična zaključka došao je i Drazen (2000) koji ističe dvije temeljne posljedice političke nestabilnosti na ekonomske performanse. Kao prvo, politička nestabilnost stvara nesigurnost u vezi s budućnosti vlade i djelovanjem njezinih institucija, što dovodi do promjena u ponašanju poduzeća, posebice u prikupljanju kapitala. Također dovodi do promjena u ponašanju same vlade koja nastoji produžiti vrijeme na vlasti ili maksimalno iskoristiti povlastice dok se još nalazi na vlasti. Kao drugo, što je i predmet istraživanja ovog rada, politička nestabilnost ima izravan utjecaj na produktivnost s obzirom na to da stvara poremećaje na tržištu i u ekonomskim odnosima.

Carmignani (1999) također ističe donošenje kratkoročnih suboptimalnih odluka vlade kod rasta političke nestabilnosti i prijetnje ostanka na vlasti. Nastala situacija dovodi do neefikasna trošenja državnih resursa, zaduživanja i akumulacije duga, neadekvatnih investicijskih odluka te u konačnici nižega ekonomskog rasta. Međutim, istraživanje Linnemana i suradnika (2016) pokazalo je da povećanje državne potrošnje u kratku roku dovodi do pada proizvodnje i radnih sati u privatnom sektoru, ali uz istodoban porast produktivnosti rada.

Potrebno je napomenuti da je u većini radova koji se bave analizom političke stabilnosti ona bila zavisna varijabla. Time se nastojalo otkriti uzroke političkih nestabilnosti kako bi se moglo predvidjeti gdje će vjerojatno doći do nestabilnosti i kako bi se sugerirali postupci za moguću prevenciju (Feierabend \& Feierabend, 1966; Gurr, 1970; Hibbs, 1973; Huntington, 1968). S druge strane, puno je manji broj radova u kojima je politička stabilnost nezavisna varijabla, što se može objasniti činjenicom da većina istraživača smatra političku stabilnost instrumentalnom ekonomskom varijablom, odnosno vjeruju da je ona nužan uvjet za gospodarski rast te da nije potrebno testirati navedenu pretpostavku (Holt \& Turner, 1966). Takoder, Goldsmith (1987) ističe da većina istraživača smatra političku stabilnost važnom te da njezine učinke nije potrebno analizirati koliko njezine uzroke. S obzirom na to da se politička stabilnost ne može direktno procijeniti, u literaturi se mjerila raznim varijablama poput broja državnih udara (Londregan \& Poole, 1990), broja političkih revolucija (Barro, 1991), promjena vlade (de Haan \& Siermann, 1996) i sličnih. Ako se promatra broj promjena vlade u posljednjih dvadesetak godina u zemljama Europske unije, primjetne su znatne razlike između pojedinih zemalja. Prema istraživanju koje provodi OEF Research (2019), Rumunji su čak 13 puta mijenjali vladu od 1996. do 2017., dok se u istom razdoblju u Luksemburgu promijenila samo 
jedanput. Također, u postsocijalističkim zemljama češće dolazi do promjena vlade (u većini više od šest puta), dok su u najrazvijenijim zemljama promjene puno rjeđe (s iznimkom Italije). Međutim, promjena vlade kao i ostale prethodno navedene varijable analiziraju samo određene aspekte političke stabilnosti te nijedna od njih nije savršena, čime dolazi do određenih pogrešaka u mjerenju i procjeni političke stabilnosti (Jong A Pin, 2006).

Drugi je pristup, koji se najviše upotrebljava u literaturi, preko posebno kreiranih indeksa (Mohamed, 2015). Indeksi se kreiraju na temelju većeg broja varijabla preko osnovne analize komponenata (npr. Alesina \& Perotti, 1996) ili preko diskriminantne analize (Gupta, 1990; Venieris \& Gupta, 1986). Nedostatak je te metode pretpostavka da je politička stabilnost jednodimenzijski koncept. Navedeno ne bi bilo znatan problem ako bi se sve relevantne poddimenzije ponašale slično te bi imale sličan utjecaj na gospodarstvo (Jong A Pin, 2006).

\section{Podatci i metodologija}

Kako bi se analizirao utjecaj političke stabilnosti na produktivnost rada, provest će se panel-analiza gdje će BDP po zaposlenom (BDP/ZAPOSL) biti zavisna varijabla u modelu. Podatci su preuzeti iz baze podataka Međunarodne organizacije rada (ILO), pri čemu je paritet kupovne moći BDP-a pretvoren u konstantne međunarodne dolare s 2011. kao baznom godinom. Međunarodni dolari imaju jednak paritet kupovne moći kao i američki dolar u Sjedinjenim Američkim Državama (International Labour Organization, 2019). Uzorak na kojem će se provesti analiza sastojat će se od 11 postsocijalističkih zemalja Europske unije: Bugarske, Hrvatske, Češke, Estonije, Mađarske, Latvije, Litve, Poljske, Rumunjske, Slovačke i Slovenije od 2000. do 2017. godine. ${ }^{1}$ Prednosti koje proizlaze iz korištenja panel-serijom podataka mogu se sažeti pod (Klevmarken, 1989; Hsiao, 2003) kontroliranje individualne heterogenosti; dobivanje više informacija, veće varijabilnosti, manje korelacije između varijabla, veće efikasnosti i većeg broja stupnjeva slobode; omogućavanje boljeg istraživanja dinamike prilagođavanja; bolje identificiranje i mjerenje efekata koji se ne mogu

1 Razdoblje prije 2000. godine nije predmet analize zbog nedostatka podataka za određene varijable u modelu, ali i činjenice da su određene postsocijalističke zemlje imale ograničenu političku konkurenciju koja se najčešće manifestirala koncentracijom političke moći u izvršnoj grani vlasti (World Bank, 2002). Navedeno označava lošu, ali istodobno stabilnu političku situaciju koja bi mogla dovesti do iskrivljenih rezultata analize. 
identificirati korištenjem isključivo usporednim podatcima ili isključivo podatcima vremenskih serija.

Kako je u literaturi prepoznato više različitih varijabla kojima se može mjeriti politička stabilnost određene zemlje, kreirat će se tri modela sa zasebnim nezavisnim varijablama za procjenu političke stabilnosti. Model 1: indikator političke stabilnosti i izostanak nasilja/terorizma (STABIL) percepcija vjerojatnosti da će vlada određene zemlje biti destabilizirana ili srušena neustavnim ili nasilnim putem, uključujući politički motivirano nasilje i terorizam (Kaufmann, Kraay \& Mastruzzi, 2010). Model 2: rizik državnog udara (RIZIK) - mjerenjem i procjenom brojnih rizičnih faktora procjenjuje se rizik državnog udara na mjesečnoj bazi koji se kreće od $0 \%$ do 100 \% (OEF Research, 2019). Model 3: državna legitimnost (LEGIT) - indikator analizira povjerenje građana u državne institucije i procese te procjenjuje posljedice nedostatka povjerenja koje se očituju u masovnim javnim demonstracijama, ignoriranju zakona ili porastom oružanih pobuna. Pritom je niža vrijednost indikatora stabilnija politička situacija (Fund For Peace, 2019).

Uz nezavisnu varijablu kojom će se procijeniti politička stabilnost pojedine zemlje, u model će se uključiti tri dodatne kontrolne nezavisne varijable: indikator percepcije korupcije (KORUP) - percepcija korupcije u javnom sektoru te se temelji na 13 upitnika i procjeni stručnjaka. Indikator poprima vrijednosti od 0 (visoka korupcija) do $100^{2}$ (izostanak korupcije) (Transparency International, 2019); bruto domaći proizvodi 15 zemalja EU-a (BDP EU15) - navedena varijabla služi za odražavanje stanja gospodarstva u 15 zemalja Europske unije koje su bile članice prije velikog proširenja 2004. (jer zemlje iz uzorka u znatnoj mjeri ovise o gospodarskim trendovima u najvećim zemljama Europske unije). Pritom se rabi BDP po konstantnim cijenama u dolarima s 2011. kao baznom godinom (UNESCO Institute for Statistics, 2019a); izdatci za istraživanje i razvoj $(R \& D)$ - varijabla važna jer istraživanje i razvoj imaju pozitivan utjecaj na produktivnost rada (Erdil, Cilasun \& Eruygur, 2013). Pritom će se procijeniti postotnim udjelom troška istraživanja i razvoja u ukupnom BDP-u kako bi se osigurala usporedivost između zemlja u uzorku (UNESCO Institute for Statistics, 2019b).

${ }^{2}$ Godine 2012. došlo je do promjene u metodologiji za izračun indikatora percepcije korupcije, čime vrijednost indikatora može poprimiti vrijednost u rasponu od 0 do 100 , a ne od 0 do 10 kako je bilo u prethodnim godinama. Kako bi se indikator mogao upotrebljavati u analizi, vrijednosti indikatora za godine koje prethode 2012. pomnožene su s deset, čime se osigurala usporedivost indikatora za cijelo promatrano razdoblje. 
Kako postoji više različitih vrsta modela za panel-analizu, provedeno je nekoliko testova kako bi se otkrio odgovarajući model. Odabir modela omogućit će da empirijsko istraživanje ne dovede do pogrešnih zaključaka poput pogrešnih vrijednosti koeficijenata modela, statističke važnosti i/ili u predznaku koeficijenta. Radi odabira odgovarajućeg modela testirano je postojanje individualnih i/ili vremenskih efekata primjenom F-testa, Breusch-Paganova testa i Hausmanova testa.

F-test upotrebljava se radi odabira između korištenja združenim modelom (engl. Pooled regression model) i modelom s fiksnim efektom (engl. Fixed-effects model). Ako rezultati testa odbace nultu hipotezu, koja govori o jednakosti konstantnih članova za sve jedinice promatranja, zaključuje se da je potrebno koristiti se modelom s fiksnim efektom. U slučaju neodbacivanja nulte hipoteze donosi se zaključak da model s fiksnim efektom nije adekvatan u procjeni te se upućuje na korištenje združenim modelom. S obzirom na nisku p-vrijednost za F-testove kod svih triju modela (Tablica 5) odbacuje se nulta hipoteza i zaključuje se da je prihvatljivije koristiti se modelima s fiksnim efektom.

Breusch-Paganovim testom testira se hipoteza o homogenosti regresorskih varijabla po promatranim jedinicama, odnosno o postojanju individualnih efekata (Breusch \& Pagan, 1979). Provođenje Breusch-Paganova testa i dobivanje niskih p-vrijednosti kod svih modela (Tablica 5) navodi na zaključak da ima statistički znatnih razlika među istraživanim zemljama pa postoji osnova da se ne prihvati združeni model, odnosno bolje je koristiti se modelom sa slučajnim efektima (engl. Random-effects model).

$\mathrm{Na}$ kraju se proveo i Hausmanov test (Tablica 5) koji uspoređuje procijenjene koeficijente modela s fiksnim i slučajnim efektom. Odbacivanje nulte hipoteze Hausmanova testa govori da je osnovna pretpostavka modela sa slučajnim efektima o nepostojanju korelacije između komponenata slučajne pogreške i zavisnih varijabla netočna te je bolje primijeniti model s fiksnim efektima (Wooldridge, 2012). Međutim, kako je kod svih modela p-vrijednost viša od 0,1 , odnosno od normalne razine signifikantnosti, ne može se odbaciti nulta hipoteza te se zaključuje da je bolje koristiti se modelom sa slučajnim efektima.

Provedeni testovi upućuju na adekvatnost primjene panel-modela sa slučajnim efektom, čime će regresijske jednadžbe imati sljedeći oblik.

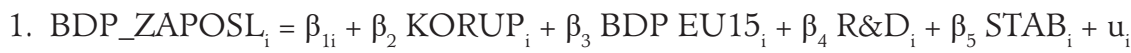

2. BDP_ZAPOSL ${ }_{\mathrm{i}}=\beta_{1 \mathrm{i}}+\beta_{2}$ KORUP $_{\mathrm{i}}+\beta_{3}$ BDP EU15 $_{\mathrm{i}}+\beta_{4} \operatorname{R}_{\mathrm{i}}+\beta_{5} \operatorname{RIZIK}_{\mathrm{i}}+\mathrm{u}_{\mathrm{i}}$

3. BDP_ZAPOSL ${ }_{\mathrm{i}}=\beta_{1 \mathrm{i}}+\beta_{2}$ KORUP $_{\mathrm{i}}+\beta_{3}$ BDP EU15 $_{\mathrm{i}}+\beta_{4}$ R\&D $_{\mathrm{i}}+\beta_{5}$ LEGIT $_{\mathrm{i}}+\mathrm{u}_{\mathrm{i}}$ 
Pritom se $\beta_{1 \mathrm{i}}(\mathrm{i}=1, \ldots, \mathrm{n})$ ne tretira kao fiksan, nego se pretpostavlja da je to slučajna varijabla sa srednjom vrijednošću $\beta_{1}$, a da je $u_{i}$ pogreška procjene. U radu će se također provjeriti robusnost modela na način da će se zamijeniti pojedine nezavisne varijable. Indikator percepcije korupcije zamijenit će se alternativnom mjerom indikatora kontrole korupcije koji izračunava Svjetska banka, a udio troška istraživanja i razvoja u ukupnom BDP-u zamijenit će se iznosom troška istraživanja i razvoja po glavi stanovnika. Dodatno će se robusnost modela procijeniti s pomoću alternativne zavisne varijable BDP-a po satu rada, koju procjenjuje OECD.

Indikator političke stabilnosti i izostanak nasilja/terorizma i indikator kontrole korupcije, koji će se upotrebljavati za dodatno testiranje robusnosti modela, pripadaju skupini svjetskih indikatora upravljanja (engl. World Governance Indicators) koje na godišnjoj razini izračunava Svjetska banka (World Bank, 2019). Njihove vrijednosti kreću se od $-2,5$ do 2,5 pri čemu viša vrijednost označava bolje stanje. Podatci potrebni za izračun navedenih indikatora prikupljaju se od raznih multilateralnih, državnih i privatnih organizacija poput Europske banke za obnovu i razvoj, francuskog Ministarstva ekonomije, industrije i zapošljavanja, Azijske banke za razvoj i drugih. Za svaki indikator upotrebljava se statistička analiza modela nevidljive komponente (engl. Analysis of Unobserved Component Models - UCM) kako bi se standardizirali podatci iz raznih izvora te kreirao jedinstveni indikator kao vagani prosjek prikupljenih podataka (Kaufmann et al., 2010.). Indikator političke stabilnosti i izostanka nasilja/terorizma odabran je za korištenje u modelu jer je upotrebljavan i u drugim radovima za procjenu političke stabilnosti određene zemlje (Jewel, 2015; Muslija, Ozbozkurt \& Satrovic, 2018).

U analizi se rabi i rizik državnog udara koji procjenjuje OEF Research na mjesečnoj razini (OEF Research, 2019) prema podatcima Powella i Thynea (2011). Navedenim podatcima koristi se i Schiel (2018) kada analizira povezanost državnih udara i stupnja demokratizacije. Za procjenu rizika državnog udara u prvoj se fazi pregledom literature identificiraju mogući uzroci te se komplementarnim log-log regresijama utvrđuje mjesečni rizik državnog udara. Zatim se metodom strojnog učenja random forest testira velik broj kombinacija varijabla kako bi se otkrilo koje kombinacije najbolje predviđaju državne udare. U konačnici se log-log regresijom kombiniraju rezultati obiju faza kako bi se kreirao jedinstven pokazatelj rizika državnog udara (Bell, 2016). Za potrebe modela izračunane su prosječne vrijednosti na godišnjoj razini.

Indikator državne legitimnosti kreira neprofitna istraživačka organizacija The Fund for Peace. Pri izračunu indikatora uzima se u obzir vladina otvorenost, posebice odnos vladajuće skupine prema transparentnosti, korup- 
ciji, profiterstvu te marginaliziranju opozicije. Indikator također analizira različite aspekte političke stabilnosti poput prirode političkih tranzicija ili, u slučajevima izostanka demokratskih izbora, stupanj u kojemu vlada predstavlja populaciju kojom upravlja (Fund For Peace, 2019).

BDP po zaposlenom upotrebljavat će se kao pokazatelj produktivnosti rada zbog bolje preciznosti, usporedivosti između promatranih zemalja te dostupnosti podataka. Postoje i drugi načini mjerenja produktivnosti poput omjera operativnih prihoda i troška zaposlenih, omjera dodane vrijednosti i troška zaposlenika, operativnog prihoda po zaposleniku i drugih (Giordano et al., 2015). Štoviše, Bernard i Jones (1996) ističu da se do 1990-ih produktivnost rada ponajprije mjerila BDP-om po stanovniku zbog nedostatka podataka o radnoj snazi.

\section{Rezultati panel-analize}

U Tablici 1 prikazana je deskriptivna analiza za promatrani uzorak. Prosječna vrijednost produktivnosti rada u promatranom razdoblju, mjerena BDP-om po zaposlenom, kreće se od 34.541 dolara u Bugarskoj do 59.730 dolara u Sloveniji. Općenito su sve zemlje u uzorku imale rastući trend produktivnosti rada u promatranom razdoblju. Ako se promatraju prosječne vrijednosti pokazatelja političke stabilnosti, indikator političke stabilnosti i izostanka nasilja/terorizma, indikator rizika državnog udara i indikator državne legitimnosti identificirali su Sloveniju kao politički najstabilniju zemlju u promatranom razdoblju. Također, sva tri indikatora Rumunjsku su označila kao zemlju s najnestabilnijom političkom situacijom. Međutim, postoje male razlike u ukupnom poretku zemalja iz uzorka koje se mogu pripisati različitim metodologijama zbog kojih dolazi do malih razlika u njihovim procjenama zemalja s najstabilnijim i najnestabilnijim političkim situacijama.

Tablica 1: Deskriptivna analiza za 11 postsocijalističkib zemlia EU-a

\begin{tabular}{|l|l|r|r|r|r|r|r|r|}
\hline \multicolumn{2}{|l|}{ Države } & BDP_ZAPOSL & KORUP & BDP EU15 & R\&D & STAB & RIZIK & LEGIT \\
\hline \multirow{3}{*}{ Bugarska } & prosjek & $34,541.04$ & 39.35 & $14,799.29$ & 0.57 & 0.26 & $0.042 \%$ & 5.27 \\
\cline { 2 - 11 } & std. dev. & $5,303.25$ & 2.70 & 871.31 & 0.16 & 0.15 & $0.016 \%$ & 0.55 \\
\cline { 2 - 10 } & $\min$ & $25,602.57$ & 33.30 & $13,206.69$ & 0.43 & 0.00 & $0.027 \%$ & 4.50 \\
\cline { 2 - 10 } & $\max$ & $41,903.95$ & 43.00 & $16,351.07$ & 0.96 & 0.47 & $0.080 \%$ & 6.00 \\
\hline
\end{tabular}


Bašić, F. (2020). Utjecaj političke stabilnosti na produktivnost rada u postsocijalističkom dijelu EU

180

HKJU-CCPA, 20(1), 171-192

\begin{tabular}{|c|c|c|c|c|c|c|c|c|}
\hline \multirow{4}{*}{ Hrvatska } & prosjek & $51,925.13$ & 41.79 & $14,799.29$ & 0.86 & 0.59 & $0.032 \%$ & 3.95 \\
\hline & std. dev. & $4,352.41$ & 5.57 & 871.31 & 0.09 & 0.10 & $0.007 \%$ & 0.61 \\
\hline & $\min$ & $42,266.14$ & 34.00 & $13,206.69$ & 0.74 & 0.28 & $0.023 \%$ & 2.90 \\
\hline & $\max$ & $56,803.42$ & 51.00 & $16,351.07$ & 1.04 & 0.75 & $0.046 \%$ & 4.80 \\
\hline \multirow{4}{*}{ Češka } & prosjek & $57,323.81$ & 47.21 & $14,799.29$ & 1.43 & 0.95 & $0.027 \%$ & 3.97 \\
\hline & std. dev. & $6,190.11$ & 6.03 & 871.31 & 0.32 & 0.19 & $0.006 \%$ & 0.49 \\
\hline & $\min$ & $46,071.73$ & 37.00 & $13,206.69$ & 1.10 & 0.33 & $0.016 \%$ & 3.40 \\
\hline & $\max$ & $65,468.73$ & 57.00 & $16,351.07$ & 1.97 & 1.11 & $0.039 \%$ & 4.90 \\
\hline \multirow{4}{*}{ Estonija } & prosjek & $50,902.75$ & 64.03 & $14,799.29$ & 1.26 & 0.70 & $0.025 \%$ & 3.91 \\
\hline & std. dev. & $6,437.63$ & 5.17 & 871.31 & 0.48 & 0.11 & $0.008 \%$ & 0.79 \\
\hline & $\min$ & $37,216.21$ & 55.00 & $13,206.69$ & 0.60 & 0.57 & $0.012 \%$ & 2.70 \\
\hline & $\max$ & $59,057.50$ & 71.00 & $16,351.07$ & 2.31 & 0.93 & $0.039 \%$ & 5.00 \\
\hline \multirow{4}{*}{ Mađarska } & prosjek & $56,321.18$ & 50.37 & $14,799.29$ & 1.09 & 0.82 & $0.032 \%$ & 5.91 \\
\hline & std. dev. & $4,030.20$ & 2.97 & 871.31 & 0.20 & 0.19 & $0.008 \%$ & 0.35 \\
\hline & $\min$ & $47,106.43$ & 45.00 & $13,206.69$ & 0.79 & 0.54 & $0.021 \%$ & 5.40 \\
\hline & $\max$ & $60,971.24$ & 55.00 & $16,351.07$ & 1.39 & 1.26 & $0.052 \%$ & 6.60 \\
\hline \multirow{4}{*}{ Latvija } & prosjek & $42,232.31$ & 45.94 & $14,799.29$ & 0.54 & 0.56 & $0.031 \%$ & 4.51 \\
\hline & std. dev. & $7,520.66$ & 7.74 & 871.31 & 0.11 & 0.22 & $0.010 \%$ & 0.67 \\
\hline & $\min$ & $28,093.86$ & 34.00 & $13,206.69$ & 0.36 & 0.20 & $0.018 \%$ & 3.40 \\
\hline & $\max$ & $52,725.45$ & 58.00 & $16,351.07$ & 0.70 & 1.00 & $0.052 \%$ & 5.40 \\
\hline \multirow{4}{*}{ Litva } & prosjek & $48,133.06$ & 50.81 & $14,799.29$ & 0.81 & 0.78 & $0.029 \%$ & 3.66 \\
\hline & std. dev. & $9,672.16$ & 5.69 & 871.31 & 0.13 & 0.14 & $0.008 \%$ & 0.53 \\
\hline & $\min$ & $30,141.58$ & 41.00 & $13,206.69$ & 0.58 & 0.42 & $0.018 \%$ & 2.70 \\
\hline & $\max$ & $59,911.02$ & 61.00 & $16,351.07$ & 1.04 & 1.05 & $0.043 \%$ & 4.40 \\
\hline \multirow{4}{*}{ Poljska } & prosjek & $48,915.42$ & 48.49 & $14,799.29$ & 0.72 & 0.70 & $0.033 \%$ & 3.83 \\
\hline & std. dev. & $6,121.99$ & 10.44 & 871.31 & 0.18 & 0.29 & $0.008 \%$ & 0.48 \\
\hline & $\min$ & $38,594.13$ & 34.00 & $13,206.69$ & 0.54 & 0.15 & $0.019 \%$ & 3.20 \\
\hline & $\max$ & $58,502.06$ & 62.00 & $16,351.07$ & 1.04 & 1.07 & $0.045 \%$ & 4.50 \\
\hline \multirow{4}{*}{ Rumunjska } & prosjek & $38,777.62$ & 36.62 & $14,799.29$ & 0.44 & 0.16 & $0.058 \%$ & 5.95 \\
\hline & std. dev. & $8,883.87$ & 7.44 & 871.31 & 0.06 & 0.18 & $0.023 \%$ & 0.34 \\
\hline & $\min$ & $21,805.51$ & 26.00 & $13,206.69$ & 0.36 & -0.38 & $0.029 \%$ & 5.20 \\
\hline & $\max$ & $52,507.86$ & 48.00 & $16,351.07$ & 0.55 & 0.46 & $0.107 \%$ & 6.40 \\
\hline \multirow{4}{*}{ Slovačka } & prosjek & $53,959.84$ & 44.32 & $14,799.29$ & 0.66 & 0.92 & $0.032 \%$ & 4.10 \\
\hline & std. dev. & $8,579.01$ & 5.51 & 871.31 & 0.20 & 0.15 & $0.008 \%$ & 0.23 \\
\hline & $\min$ & $40,113.52$ & 35.00 & $13,206.69$ & 0.45 & 0.59 & $0.022 \%$ & 3.70 \\
\hline & $\max$ & $64,574.29$ & 51.00 & $16,351.07$ & 1.18 & 1.12 & $0.051 \%$ & 4.50 \\
\hline
\end{tabular}




\begin{tabular}{|l|l|r|r|r|r|r|r|r|}
\hline \multirow{3}{*}{ Slovenija } & prosjek & $59,730.26$ & 61.10 & $14,799.29$ & 1.82 & 1.02 & $0.023 \%$ & 2.89 \\
\cline { 2 - 9 } & std. dev. & $5,189.80$ & 3.33 & 871.31 & 0.45 & 0.12 & $0.007 \%$ & 0.20 \\
\cline { 2 - 9 } & $\min$ & $50,540.67$ & 55.00 & $13,206.69$ & 1.25 & 0.87 & $0.015 \%$ & 2.60 \\
\cline { 2 - 9 } & $\max$ & $67,169.38$ & 67.00 & $16,351.07$ & 2.58 & 1.30 & $0.045 \%$ & 3.20 \\
\hline
\end{tabular}

Izvor: obrada autora

Korelacijska matrica regresijskih varijabla upotrebljavala se za analizu jačine veza između regresorskih varijabla. Prema Evansu (1996) vrijednost koeficijenata korelacije ispod 0,4 označava slabu vezu, između 0,4 i 0,59 umjerenu, dok su vrijednosti od 0,6 i više jaka veza. Tablice 2, 3 i 4 pokazuju korelacijske matrice za modele 1,2 i 3 . U sva tri modela primjetna je jaka veza između zavisne varijable (BDP/ZAPOSL) i izdataka za istraživanje i razvoj. Jaka je i umjereno jaka i veza indikatora percepcije korupcije sa zavisnom varijablom, dok veza zavisne varijable i BDP za EU15 varira od izrazito jake $(0,608)$ do slabe $(0,264)$. Što se tiče korelacije s pokazateljima političke stabilnosti, postoji jaka pozitivna veza između BDP-a po zaposlenom i indikatora političke stabilnosti i izostanka nasilja/terorizma $(0,613)$. S druge strane, postoji jaka negativna veza s indikatorom rizika državnog udara $(-0,648)$ te umjerena negativna veza s indikatorom državne legitimnosti $(-0,562)$.

Tablica 2: Korelacijska matrica varijabla za model 1

\begin{tabular}{|l|c|c|c|c|c|}
\hline & BDP/ZAPOSL & KORUP & BDP EU15 & R_D & STAB \\
\hline BDP/ZAPOSL & 1 & 0,649379 & 0,578011 & 0,684812 & 0,613057 \\
\hline KORUP & 0,649379 & 1 & 0,414306 & 0,628974 & 0,480961 \\
\hline BDP EU15 & 0,578011 & 0,414306 & 1 & 0,256808 & 0,001517 \\
\hline R_D & 0,684812 & 0,628974 & 0,256808 & 1 & 0,483032 \\
\hline STAB & 0,613057 & 0,480961 & 0,001517 & 0,483032 & 1 \\
\hline
\end{tabular}

Izvor: obrada autora

Tablica 3: Korelacijska matrica varijabla za model 2

\begin{tabular}{|c|c|c|c|c|c|}
\hline & BDP/ZAPOSL & KORUP & BDP EU15 & R_D & EFW \\
\hline BDP/ZAPOSL & 1 & 0,655798 & 0,608041 & 0,688508 & $-0,647785$ \\
\hline KORUP & 0,655798 & 1 & 0,431359 & 0,629719 & $-0,555325$ \\
\hline BDP EU15 & 0,608041 & 0,431359 & 1 & 0,279433 & $-0,402361$ \\
\hline
\end{tabular}




\begin{tabular}{|l|c|c|c|c|c|}
\hline R_D & 0,688508 & 0,629719 & 0,279433 & 1 & $-0,507070$ \\
\hline RIZIK & $-0,647785$ & $-0,555325$ & $-0,402631$ & $-0,507070$ & 1 \\
\hline
\end{tabular}

Izvor: obrada autora

Tablica 4: Korelacijska matrica varijabla za model 3

\begin{tabular}{|l|c|c|c|c|c|}
\hline & BDP/ZAPOSL & KORUP & BDP EU15 & R_D & LEGIT \\
\hline BDP/ZAPOSL & 1 & 0,578944 & 0,264651 & 0,653605 & $-0,562476$ \\
\hline KORUP & 0,578944 & 1 & 0,237599 & 0,602466 & $-0,605626$ \\
\hline BDP EU15 & 0,264651 & 0,237599 & 1 & 0,063712 & $-0,213023$ \\
\hline R_D & 0,653605 & 0,602466 & 0,063712 & 1 & $-0,457248$ \\
\hline LEGIT & $-0,562476$ & $-0,605626$ & $-0,213023$ & $-0,457248$ & 1 \\
\hline
\end{tabular}

Izvor: obrada autora

Tablica 5 prikazuje rezultate panel-analize ${ }^{3}$, s tim da u modelu 1 nije analizirana 2001. godina jer za nju ne postoje podatci o vrijednosti indikatora političke stabilnosti i izostanka nasilja/terorizma. Niske p-vrijednosti uz varijable pokazuju da je, pri razini signifikantnosti od $1 \%$, većina varijabla značajna u modelu. Dobiveni predznaci koeficijenata u skladu su s očekivanjima te u svim modelima prikazuju da smanjenje korupcije (rast vrijednosti indikatora percepcije korupcije), povećanje bruto domaćeg proizvoda EU15 te povećanje izdataka za istraživanje i razvoj imaju pozitivan učinak na produktivnost rada mjerenu BDP-om po zaposlenom. Kod varijabla za mjerenje političke stabilnosti rast vrijednosti indikatora političke stabilnosti i izostanka nasilja/terorizma za jedan bod u prosjeku dovodi do povećanja produktivnosti mjerene BDP-om po zaposlenom za $2.518,65$ američkih dolara. Istodobno porast indikatora rizika državnog udara za 0,01 postotni bod, uz ostale uvjete nepromijenjene, u prosjeku dovodi do smanjenja BDP-a po zaposlenom za 92.424,51 američki dolar. Na sličan način utječe i indikator državne legitimnosti čije povećanje od jednog boda dovodi do prosječnog pada BDP-a po zaposlenom od 1.082,29 američkih dolara. Od navedenih varijabla indikator političke stabilnosti i izostanka nasilja/terorizma značajan je na razini signifikantnosti od $5 \%$, dok su ostale dvije ključne nezavisne varijable za mjerenje političke stabilnosti značajne i na razini signifikantnosti od $1 \%$.

\footnotetext{
${ }^{3}$ Ekonometrijska analiza provedena je korištenjem programom EViews (verzija 9).
} 
Visoka vrijednost koeficijenta za varijablu rizika državnog udara u modelu 2 rezultat je vrlo niske vjerojatnosti državnog udara koja se u uzorku kreće od 0,012 \% (Estonija 2012) do 0,107 \% (Rumunjska 2009). Navedeno je posljedica stabilnosti i unutarnjeg uređenja država u uzorku u promatranom razdoblju, ali i metodologije koja se rabi za izračun rizika državnog udara. Prema metodologiji kojom se koristi OEF Research, velika većina procjena vrlo je mala i blizu 0 , što pokazuje i relativnu točnost procjene $s$ obzirom na to da su se državni udari dogodili u 0,3 \% slučajeva, odnosno u manje od 500 mjeseci od gotovo 130.000 mjeseci prema kojima je procjena kreirana (Bell, 2016).

S obzirom na ispravne predznake ključnih nezavisnih varijabla u sva tri modela, uz činjenicu da su korištene varijable značajne pri normalnim razinama signifikantnosti, može se zaključiti da povećanje političke stabilnosti dovodi do povećanja produktivnosti rada mjerene BDP-om po zaposlenom. Međutim, potrebno je istaknuti određena ograničenja provedene analize zbog kojih se dobiveni rezultati trebaju uzeti s dozom zadrške. U prvom redu problematično je relativno kratko razdoblje analize, posebice u modelu 3. Navedeno je posljedica kratkih razdoblja ključnih nezavisnih varijabla s obzirom na to da se politička stabilnost počela procjenjivati specijalnim indeksima tek krajem dvadesetog stoljeća. Razvijenije zemlje imaju nešto duže vremenske serije, ali za postsocijalističke zemlje Europske unije podatci većinom postoje najviše za posljednjih dvadesetak godina. Drugo je bitno ograničenje $u$ istraživanju nedostatak državnih udara i oružanih sukoba izazvanih političkom situacijom u zemljama u uzorku. Postavlja se pitanje bi li takvi ekstremni primjeri političke nestabilnosti imali puno drastičniji utjecaj na produktivnost rada.

Tablica 5: Rezultati panel-analize za 11 postsocijalističkih zemlja EU-a

\begin{tabular}{|l|c|c|c|}
\hline \multirow{4}{*}{ varijabla } & \multicolumn{3}{|c|}{ kavisna varijabla: BDP/ZAPOSL } \\
\cline { 2 - 4 } & model 1 & model 2 & model 3 \\
\hline C & $-45128,01(0,0000)$ & $-35707,75(0,0000)$ & $-2094,244(0,7569)$ \\
\hline KORUP & $238,1967(0,0000)$ & $257,9476(0,0000)$ & $204,1154(0,0000)$ \\
\hline BDP EU15 & $5,303613(0,0000)$ & $4,992734(0,0000)$ & $2,832181(0,0000)$ \\
\hline R_D & $3148,614(0,0001)$ & $1941,490(0,0138)$ & $2294,939(0,0023)$ \\
\hline STAB & $2518,650(0,0169)$ & - & - \\
\hline RIZIK & - & $-9242451(0,0000)$ & - \\
\hline LEGIT & - & - & $-1082,285(0,0046)$ \\
\hline
\end{tabular}




\begin{tabular}{|l|c|c|c|}
\hline broj opažanja & 187 & 197 & 121 \\
\hline broj zemalja & 11 & 11 & 11 \\
\hline \multirow{2}{*}{ duljina razdoblja } & 17 & 18 & 11 \\
\hline $\mathrm{R}^{2}$ & $(2000 .-2017)$. & $(2000 .-2017)$. & $(2007 .-2017)$. \\
\hline F-test p & 0,836102 & 0,875460 & 0,676979 \\
\hline Breusch-Pagan $\mathrm{p}$ & 0,0000 & 0,0000 & 0,0000 \\
\hline Hausman $\mathrm{p}$ & 1,0000 & 0,0000 & 0,0000 \\
\hline
\end{tabular}

Izvor: obrada autora

\section{Testiranje robusnosti}

Kako bi se dodatno testirala robusnost rezultata, navedeni regresijski modeli procijenjeni su alternativnim varijablama. $U$ prvom slučaju indikator percepcije korupcije zamijenjen je indikatorom kontrole korupcije (ALTER KORUP) koji označava percepciju korištenja javnim djelovanjem za privatne svrhe, uključujući male i velike oblike korupcije, kao i utjecaj privatnih interesa u djelovanju države (Kaufmann et al., 2010). Rezultati panel-analize s alternativnom mjerom korupcije prikazani su u Tablici 6 te je vidljivo da rast vrijednosti indikatora političke stabilnosti i izostanka nasilja/terorizma od jednog boda, ceteris paribus, u prosjeku dovodi do rasta BDP-a po zaposlenom za 2.869,16 američkih dolara. Kod povećanja političke nestabilnosti prikazane rastom rizika državnog udara za 0,01 postotni bod u prosjeku dolazi do smanjenja BDP-a po zaposlenom za $82.475,57$ američkih dolara. Također, rast indikatora državne legitimnosti od jednog boda dovodi do prosječnog pada BDP-a po zaposlenom za 910,34 američka dolara. Varijable u sva tri modela zadržale su prije utvrđene predznake te je jedino došlo do blagih promjena u razinama signifikantnosti pojedinih varijabla. Značajnost indikatora političke stabilnosti i izostanka nasilja/terorizma porasla je na razinu signifikantnosti od $1 \%$, dok se značajnost indikatora državne legitimnosti spustila na razinu signifikantnosti od $5 \%$. 
Tablica 6: Rezultati panel-analize s alternativnom mjerom korupcije

\begin{tabular}{|c|c|c|c|}
\hline \multicolumn{4}{|c|}{ zavisna varijabla: BDP/ZAPOSL } \\
\hline \multirow{2}{*}{ varijabla } & \multicolumn{3}{|c|}{ koeficijent } \\
\hline & model 1 & model 2 & model 3 \\
\hline $\mathrm{C}$ & $-50600,61(0,0000)$ & $-40291,48(0,0000)$ & $2828,064(0,6805)$ \\
\hline ALTER KORUP & $6393,164(0,0000)$ & $6366,525(0,0000)$ & $6609,170(0,0000)$ \\
\hline BDP EU15 & $6,264879(0,0000)$ & $5,941188(0,0000)$ & $3,223150(0,0000)$ \\
\hline R_D & $3346,865(0,0001)$ & $2403,283(0,0036)$ & $2847,360(0,0003)$ \\
\hline STAB & $2869,164(0,0072)$ & - & - \\
\hline RIZIK & - & $-8247557(0,0000)$ & - \\
\hline LEGIT & - & - & $-910,3381(0,0254)$ \\
\hline broj opažanja & 187 & 187 & 121 \\
\hline broj zemalja & 11 & 11 & 11 \\
\hline duljina razdoblja & $\begin{array}{c}17 \\
(2000 .-2017 .) \\
\end{array}$ & $\begin{array}{c}17 \\
(2000 .-2017 .) \\
\end{array}$ & $\begin{array}{c}11 \\
(2007 .-2017 .) \\
\end{array}$ \\
\hline $\mathrm{R}^{2}$ & 0,834965 & 0,855114 & 0,668312 \\
\hline F-test p & 0,0000 & 0,0000 & 0,0000 \\
\hline Breusch-Pagan p & 0,0000 & 0,0000 & 0,0000 \\
\hline Hausman p & 1,0000 & 1,0000 & 0,8497 \\
\hline
\end{tabular}

Izvor: obrada autora

U drugom slučaju udio troška istraživanja i razvoja u ukupnom BDP-u zamijenjen je iznosom troška istraživanja i razvoja po glavi stanovnika (R_D PER CAPITA) po konstantnim cijenama u dolarima s 2005. kao baznom godinom (UNESCO Institute for Statistics, 2019b). Tablica 7 takoder ne prikazuje promjene u predznacima pojedinih varijabla, ali se smanjila razina značajnosti indikatora političke stabilnosti i izostanka nasilja/terorizma na razinu signifikantnosti od $10 \%$. Koeficijenti ključnih nezavisnih varijabla u modelima pokazuju da će povećanje indikatora političke stabilnosti i izostanka nasilja/terorizma za jedan bod u prosjeku dovesti do povećanja BDP-a po zaposlenom za 2.036,73 američka dolara, povećanje rizika državnog udara za 0,01 postotni bod, u prosjeku smanjiti BDP po zaposlenom za 95.157,09 američkih dolara, a povećanje indikatora državne legitimnosti od jednog boda, uz ostale će varijable nepromijenjene, utjecati na prosječno smanjenje BDP-a po zaposlenom za 1.166,49 američkih dolara. 
Tablica 7: Rezultati panel-analize s alternativnom mjerom istraživanja $i$ razvoja

\begin{tabular}{|l|c|c|c|}
\hline \multicolumn{4}{|c|}{ zavisna varijabla: BDP/ZAPOSL } \\
\hline \multirow{2}{*}{ varijabla } & \multicolumn{3}{|c|}{ koeficijent } \\
\cline { 2 - 4 } & model 1 & model 2 & model 3 \\
\hline C & $-40563,69(0,0000)$ & $-31780,77(0,0000)$ & $7521,997(0,2687)$ \\
\hline KORUP & $236,9005(0,0000)$ & $256,0448(0,0000)$ & $194,1807(0,0000)$ \\
\hline RDPD EU15 PER CA- & $5,061467(0,0000)$ & $4,745552(0,0000)$ & $2,517164(0,0000)$ \\
PITA & $13,30398(0,0001)$ & $9,789401(0,0039)$ & $12,64434(0,0003)$ \\
\hline STAB & $2036,725(0,0534)$ & - & - \\
\hline RIZIK & - & -9515709 & - \\
\hline LEGIT & - & $(0,0000)$ & 11 \\
\hline broj opažanja & 187 & - & $1167,490(0,0020)$ \\
\hline broj zemalja & 11 & 11 & $(2007 .-2017)$. \\
\hline duljina razdoblja & $(2000 .-2017)$. & $(2000 .-2017)$. & 0,687493 \\
\hline$R^{2}$ & 0,839720 & 0,876735 & 0,0000 \\
\hline F-test p & 0,0000 & 0,0000 & 0,0000 \\
\hline Breusch-Pagan p & 0,0000 & 0,0000 & 0,7959 \\
\hline Hausman p & 1,0000 & 0,2320 & 121 \\
\hline
\end{tabular}

Izvor: obrada autora

U posljednjem koraku testiranja robusnosti zavisna varijabla BDP-a po zaposlenom zamijenjena je alternativnom mjerom BDP-a po satu rada. Kod procjene BDP-a po satu rada posebno je problematična procjena radnih sati. Ahmad i suradnici (2003) ističu problem procjene radnih sati u sličnim istraživanjima te navode da su administrativni izvori poput socijalnih baza podataka ograničeni na osobe koje su pokrivene relevantnim regulacijama. Osim toga, opseg anketa o zaposlenicima ili poduzećima često ne uključuje poljoprivrednike, menadžere, zaposlene u javnoj administraciji, pružatelje osobnih usluga, mala poduzeća i vojnike. Podatci o BDP-u po satu rada preuzeti su iz baze podataka OECD-a (2019) te su izraženi u dolarima s 2010. kao baznom godinom. Pritom je ljudski input procijenjen ukupnim brojem sati svih osoba uključenih u proizvodni proces. Također je potrebno istaknuti da dobivena mjera samo djelomično reflektira osobne kapacitete radnika i intenzitet njihova rada (OECD 2019). 
U Tablici 8 dobiveni rezultati pokazuju da će povećanje indikatora političke stabilnosti i izostanka nasilja/terorizma za jedan bod, ceteris paribus, u prosjeku dovesti do povećanja BDP-a po satu rada od 1,31 američkog dolara. S druge strane, povećanje rizika državnog udara za 0,01 postotni bod utječe u prosjeku na smanjenje BDP-a po satu rada za 39,53 američka dolara. Također, rast indikatora državne legitimnosti od jednog boda u prosjeku će rezultirati smanjenjem BDP-a po satu rada od 0,46 američkih dolara. Pritom se najvažnija promjena dogodila u modelu tri, gdje se značajnost ključne nezavisne varijable indikatora državne legitimnosti smanjila na razinu signifikantnosti od $10 \%$.

Tablica 8: Rezultati panel-analize s alternativnom mjerom produktivnosti

\begin{tabular}{|c|c|c|c|}
\hline \multicolumn{4}{|c|}{ zavisna varijabla: BDP/SAT RADA } \\
\hline \multirow{2}{*}{ varijabla } & \multicolumn{3}{|c|}{ koeficijent } \\
\hline & model 1 & model 2 & model 3 \\
\hline $\mathrm{C}$ & $-31,49248(0,0000)$ & $-27,50408(0,0000)$ & $-13,35311(0,0024)$ \\
\hline KORUP & $0,154292(0,0000)$ & $0,162239(0,0000)$ & $0,179342(0,0000)$ \\
\hline BDP EU15 & $0,003213(0,0000)$ & $0,003095(0,0000)$ & $0,002176(0,0000)$ \\
\hline R_D & $2,736046(0,0000)$ & $2,205924(0,0000)$ & $2,197011(0,0000)$ \\
\hline STAB & $1,305555(0,0226)$ & - & - \\
\hline RIZIK & - & $-3952,901(0,0002)$ & - \\
\hline LEGIT & - & - & $-0,455419(0,0578)$ \\
\hline broj opažanja & 187 & 197 & 121 \\
\hline broj zemalja & 11 & 11 & 11 \\
\hline duljina razdoblja & $\begin{array}{c}17 \\
(2000 .-2017 .)\end{array}$ & $\begin{array}{c}18 \\
(2000 .-2017 .)\end{array}$ & $\begin{array}{c}11 \\
(2007 .-2017 .)\end{array}$ \\
\hline $\mathrm{R}^{2}$ & 0,866877 & 0,898742 & 0,753687 \\
\hline F-test p & 0,0000 & 0,0000 & 0,0000 \\
\hline Breusch-Pagan $\mathrm{p}$ & 0,0000 & 0,0000 & 0,0000 \\
\hline Hausman $\mathrm{p}$ & 1,0000 & 0,4894 & 0,8184 \\
\hline
\end{tabular}

Izvor: obrada autora

Dobiveni rezultati pokazuju robusnost $\mathrm{u}$ alternativnim specifikacijama s obzirom na to da se predznaci nezavisnih varijabla nisu mijenjali niti su varijable postale nesignifikantne pri normalnim razinama značajnosti. Stoga se može zaključiti da su inicijalni regresijski modeli dobro formulirani i da su dobiveni rezultati pouzdani. 


\section{Zaključak}

Brojnim je istraživanjima pokazano da stabilna politička situacija u zemlji ima pozitivan utjecaj na ekonomske performanse te da političke promjene dovode do nesigurnosti u donošenju poslovnih odluka. Međutim, izrazito se malen broj radova bavio utjecajem političke stabilnosti na produktivnost određene zemlje, posebice na produktivnost rada. Ovim se radom nastojala popuniti rupa u navedenom području te dodatno upozoriti na važnost političke stabilnosti u suvremenim ekonomijama.

Pregledom literature ustanovljeno je da ne postoji jedinstven način izračuna političke stabilnosti određene zemlje, već se ona procjenjuje različitim varijablama i posebno kreiranim indeksima. U radu su se upotrebljavala tri indeksa koji na različite načine procjenjuju trajanje i kontinuitet vlade određene zemlje, postojanje legitimnoga ustavnog uređenja, izostanak nasilnih političkih događaja i sličnog kako bi se utvrdio stupanj političke stabilnosti. S pomoću njih kreirana su tri modela kojima je pokazano da politička stabilnost ima znatan utjecaj na produktivnost rada u postsocijalističkim zemljama, članicama Europske unije te ju je potrebno uzeti u obzir pri budućim analizama produktivnosti. Rezultati analize također su robusni za alternativne mjere istraživanja i razvoja te korupcije. Dodatno je robusnost inicijalnih modela potvrđena korištenjem alternativne zavisne varijable BDP-a po satu rada. Nedostatak istraživanja relativno je kratko razdoblje analize te nedostatak državnih udara i oružanih sukoba izazvanih političkom situacijom na zemljama u uzorku.

Ovim je radom ponajprije pokriven postsocijalistički dio Europske unije koji karakterizira relativno visok stupanj demokracije te se postavlja pitanje kakvi bi efekti bili u zemljama u kojima to nije slučaj. Također, daljnja istraživanja trebala bi obuhvatiti i slabije razvijene zemlje gdje je politička nestabilnost posebice izražena.

\section{Popis literature}

Ahearn, M. C., Yee, J., \& Huffman, W. (2002). The impact of government policies on agricultural productivity and structure: Preliminary results. American Agricultural Economics Association, 2002 Annual meeting. Dostupno na https://webcache.googleusercontent.com/search?q=cache:hkAoJBRPWMgJ:https://ageconsearch.umn.edu/record/19865/files/sp02ah02.pd$\mathrm{f}+\& \mathrm{~cd}=2 \& \mathrm{hl}=\mathrm{hr} \& \mathrm{ct}=\mathrm{clnk} \& \mathrm{gl}=\mathrm{hr}$.

Ahmad, N., Lequiller, F., Marianna, P., Pilat, D., Schreyer, P., \& Wölfl, A. (2003). Comparing labour productivity growth in the OECD area: the role of meas- 
urement. OECD Science, Technology and Industry Working Papers, 2003/14, https://doi.org/10.2139/ssrn.1690929.

Aisen, A., \& Veiga, F. J. (2011). How does political instability affect economic growth?. European Journal of Political Economy, 29, 151-167, https://doi. org/10.1016/j.ejpoleco.2012.11.001.

Akongdit, A. (2013). Impact of political stability on economic development: Case of South Sudan. Bloomington, SAD: Author House.

Alesina, A., Ozler, S., Roubini, N., \& Swagel, P. (1996). Political instability and economic growth. Journal of Economic Growth, 1(2), 189-211, https://doi. org/10.3386/w4173.

Alesina, A., \& Perotti, R. (1996). Income distribution, political instability, and investment. European Economic Review, 40(6), 1203-1228, https://doi. org/10.1016/0014-2921(95)00030-5.

Barro, R. J. (1991). Economic growth in a cross section of countries. Quarterly Journal of Economics, 106(2), 407-443.

Bell, C. (2016). The rulers, elections, and irregular governance dataset (REIGN) [Opis metodologije]. OEF Research. Dostupno na https://oefresearch.org/ activities/coup-cast/methodology.

Bernard, A. B., \& Jones, C. I. (1996). Comparing apples to oranges: Productivity convergence and measurement across industries and countries. The American Economic Review, 86(5), 1216-1238, https://doi.org/10.1257/aer.91.4.1168.

Borkovic, S., \& Tabak, P. (2018). Public investment and corporate productivity in Croatia. Public Sector Economics, 42(2), 171-186.

Breusch, T. S., \& Pagan, A. R. (1979). A simple test for heteroscedasticity and random coefficient variation. Econometrica: Journal of the Econometric Society, 47(5), 1287-1294, https://doi.org/10.2307/1911963.

Carmignani, F. (1999). Measures of political instability in multiparty governments:a new data-set with econometric applications. Discussion Paper in Economics, University of Glasgow, No. 9916.

Castles, F. G. (1974). Political stability and the dominant image of society. Political Studies, 22(3), 289-298, https://doi.org/10.1111/j.1467-9248.1974. tb00027.x.

de Haan, J., \& Siermann, C. L. J. (1996). Political instability, freedom, and economic growth: some further evidence. Economic Development and Cultural Change, 44(2), 339-350, https://doi.org/10.1086/452217.

Dimitraki, O. (2010). Political instability and economic growth in western Europe: a causality analysis for 55 years. 3rd PbD Conference in Economics 2010 Brunel University, West London, UK.

Drazen, A. (2000). Political economy in macroeconomics. New Jersey, SAD: Princeton University Press.

Erdil, E., Cilasun, S. M., \& Eruygur, A. (2013). Do R\&D expenditure matter for labor productivity in OECD countries? An unresolved question. Hacettepe Üniversitesi İktisadi ve İdari Bilimler Fakültesi Dergisi, 31(1), 71-82, https://doi. org/10.17065/huniibf.103656. 
Evans, J. D. (1996). Straightforward statistics for the behavioral sciences, Pacific Grove, SAD: Brooks / Cole Pub. Co.

Feierabend, I. K., \& Feierabend, R. L. (1966). Aggressive behaviors within polities, 1948-1962: a cross national study. Journal of Conflict Resolution, 10(9), 249-71, https://doi.org/10.1177/002200276601000301.

Fernald, J. G. (1999). Roads to prosperity? Assessing the link between public capital and productivity. The American Economic Review, 89(3), 619-638, https:// doi.org/10.1257/aer.89.3.619.

Fund For Peace (2019). Fragile states index [Statistički izvještaj]. Dostupno na https://fragilestatesindex.org/data/.

Giordano, R., Lanau, S., Tommasino, P., \& Topalova, P. (2015). Does public sector inefficiency constrain firm productivity: Evidence from Italian provinces. IMF working paper, 15/168: 26, https://doi.org/10.5089/9781513580630.001.

Goldsmith, A. (1987). Does political stability hinder economic development? Mancur Olson's theory and the Third World. Comparative Politics, 19(4), 471-80, https://doi.org/10.2307/421818.

Gupta, D. K. (1990). The economics of political violence: The effect of political instability on economic growth. New York, SAD: Praeger.

Gurr, T. R. (1970). Why men rebel. New Jersey, SAD: Princeton University Press.

Hibbs, D. A. (1973). Mass political violence: a cross-national causal analysis. New York, SAD: John Wiley \& Sons.

Holt, R. T., \& Turner, J. E. (1966). The political basis of economic development: an exploration in comparative political analysis. Princeton, New Jersey, SAD: D. Van Nostrand \& Company.

Hsiao, C. (2003). Analysis of panel data. Cambridge, UK: Cambridge University Press. Huntington, S. P. (1968). Political order in changing societies. New Haven, SAD: Yale University Press.

Hunvitz, L. (1973). Contemporary approaches to political stability. Comparative Politics, 5(4), 49-63.

International Labour Organization (2019). Labour productivity - ILO modelled estimates [Statistički izvještaj]. Dostupno na https://www.ilo.org/ilostat/faces/ oracle/webcenter/portalapp/pagehierarchy/Page3.jspx?MBI_ID=49\&_afrLo$\mathrm{op}=4676849688265802 \& \_$_afrWindowMode $=0 \& \_$afrWindowId $=i$ hnu6tzwx _1\#!\%40\%40\%3F_afrWindowId\%3Dihnu6tzwx_1\%26_afrLoop\%3D467684 9688265802\%26MBI_ID\%3D49\%26_afrWindowMode\%3D0\%26_adf.ctrlstate\%3Dihnu6tzwx_131.

Jewel, F. R. (2015). Political stability, foreign direct investment and remittance inflow in Bangladesh: An empirical analysis. Halifax, Kanada: Saint Mary's University.

Jong A Pin, R. (2006). On the measurement of political instability and its impact on economic growth. European Journal of Political Economy, 25(1), 15-29, https://doi.org/10.1016/j.ejpoleco.2008.09.010.

Kaufmann, D., Kraay, A., \& Mastruzzi, M. (2010). The worldwide governance indicators methodology and analytical issues. World Bank Policy Research Working Paper, No. 5430, https://doi.org/10.1596/1813-9450-5430. 
Klevmarken, N. A. (1989). Panel studies: What can we learn from them? Introduction. European Economic Review, 33(2-3), 523-529.

Kneller, R., \& Misch, F. (2013). The effects of public spending composition on firm productivity. Economic Inquiry, 52(4), 1525-1542, https://doi.org/10.1111/ ecin. 12092.

Linnemann, L., Uhrin, G. B., \& Wagner, M. (2016). Government spending shocks and labor productivity. Discussion papers / Technische Universität Dortmund Fakultät Statistik, SFB 823.

Lipset, S. M. (1963). Political man: The social bases of politics. London, UK: Mercury.

Londregan, J. B., \& Poole, K. T. (1990). Poverty, the coup trap, and the seizure of executive power. World Politics, 42(2), 151-183, https://doi.org/10.2307/2010462.

Matta, S., Appleton, S., \& Bleaney, M. (2017). The economic impact of political instability and mass civil protest. Discussion Papers, 2017-03, University of Nottingham, CREDIT.

Mohamed, M. (2015). The role of political stability in achieving economic development. Journal of Economics and Sustainable Development, 6(16), 134-153.

Muslija, A., Ozbozkurt, O. B., \& Satrovic, E. (2018). On the relationship between tourism and political stability and absence of violence/terrorism. 1st International Congress of Political, Economic and Financial Analysis - 2018 (str. 11751184). Nazilli/Aydin (Turska): PEFA.

OECD (2019). GDP per hour worked [Statistički izvještaj]. Dostupno na https:// data.oecd.org/lprdty/gdp-per-hour-worked.htm, https://doi.org/10.1787/ pdtvy-2013-graph7-en.

OEF Research (2019). The rulers, elections, and irregular governance dataset (REIGN) [Statistički izvještaj]. Dostupno na https://oefdatascience.github.io/REIGN.github.io/menu/reign_current.html.

Overland, J., Simons, K. L., \& Spagat, M. (2005). Political instability and growth in Dictatorships. Public Choice, 125(3-4), 445-470, https://doi.org/10.1007/ s11127-005-3060-0.

Powell, J., \& Thyne, C. (2011). Global instances of coups from 1950-Present. Journal of Peace Research, 48(2), 249-259, https://doi.org/10.1177/0022343310397436.

Salotty, S., \& Trecroci, C. (2016). The impact of government debt, expenditure and taxes on aggregate investment and productivity growth. Economica, 83(330), 356-384, https://doi.org/10.1111/ecca.12175.

Schiel, R. E. (2018). The conditionality of vulnerability: three analyses of risk and opportunity in civil military relations. Electronic Theses and Dissertations, 6179. Dostupno na https://stars.library.ucf.edu/etd/6179.

Solow, R. (1957). Technical change and the aggregate disturbances to industrial output in seven European countries. Journal of Monetary Economics, 21, 387-409.

Transparency International (2019). Corruption perceptions index [Opis metodologije]. Dostupno na https://www.transparency.org/files/content/pages/ CPI_2018_Executive_Summary_EN.pdf. 
UNESCO Institute for Statistics (2019a). Dataset: Demographic and socio-economic [Statistički izvještaj]. Dostupno na http://data.uis.unesco.org/index. aspx?queryid $=74 \#$.

UNESCO Institute for Statistics (2019b). Gross domestic expenditure on R\&D (GERD), GERD as a percentage of GDP, GERD per capita and GERD per researcher [Statistički izvještaj]. Dostupno na http://data.uis.unesco.org/index. aspx?queryid=74, https://doi.org/10.1787/msti-v2009-1-table4-en-fr.

Venieris, Y., \& Gupta, D. (1986). Income distribution and sociopolitical instability as determinants of savings: a cross-sectional model. Journal of Political Economy, 94, 873-883, https://doi.org/10.1086/261412.

Wooldridge, J. M. (2012). Introductory econometrics: A modern approach. Mason, SAD: Cengage Learning.

World Bank (2002). Transition, the first ten years: analysis and lessons for Eastern Europe and the Former Soviet Union [Izvještaj]. Dostupno na http://siteresources. worldbank.org/ECAEXT/Resources/complete.pdf, https://doi.org/10.1596/08213-5038-2.

World Bank (2019). The Worldwide governance indicators leaders [Statistički izvještaj]. Dostupno na http://info.worldbank.org/governance/wgi/\#home.

\section{INFLUENCE OF POLITICAL STABILITY ON LABOUR PRODUCTIVITY IN POST-SOCIALIST COUNTRIES OF THE EUROPEAN UNION}

\section{Summary}

Economic performance of a specific country is, to a large extent, affected by political stability. The aim of this paper is to show that political stability has a significant impact on labour productivity measured by GDP per person employed. An analysis has been made using the random-effects model on three different measures for estimating political stability of a specific country: political stability and absence of violence/terrorism, risk of coup, and state legitimacy. The sample consists of 11 post-socialist EU countries for the period between 2000 and 2017. The results indicate that political stability has a significant impact on labour productivity in post-socialist European countries. The robustness of results has been further conferment by alternative model specification. Given the fact that the majority of existing literature focuses on the causes of political instability and the measures of preventing them, this paper primarily points out the consequences of political instability on labour productivity and the economy. Keywords: political stability, labour productivity, post-socialist countries, European Union 